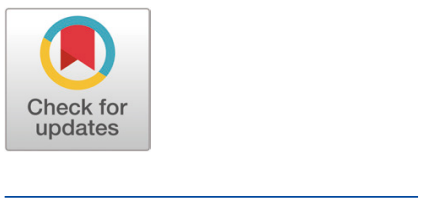

Received: May 21, 2020

Revised: May 27, 2020

Accepted: May 31, 2020

\#These authors contributed equally to this work.

*Corresponding author Jinho Cho

Department of Animal Science, Chungbuk National University,

Cheongju 28644, Korea.

Tel: +82-43-261-2548

E-mail: jinhcho@cbnu.ac.kr

Hyeun Bum Kim

Department of Animal Resources and Science, Dankook University,

Cheonan 31116, Korea.

Tel: +82-41-550-3653

E-mail: hbkim@dankook.ac.kr

Copyright $\odot 2020$ Korean Society of Animal Sciences and Technology.

This is an Open Access article distributed under the terms of the Creative Commons Attribution Non-Commercial License (http:// creativecommons.org/licenses/by$\mathrm{nc} / 4.0 /$ ) which permits unrestricted non-commercial use, distribution, and reproduction in any medium, provided the original work is properly cited.

ORCID

Won Yun

https://orcid.org/0000-0002-1835-2640

Minho Song

https://orcid.org/0000-0002-4515-5212 Jihwan Lee

https://orcid.org/0000-0001-8161-4853

\section{Arginine addition in a diet for wean- ing pigs can improve the growth performance under heat stress}

\author{
Won Yun ${ }^{1 \#, ~ M i n h o ~ S o n g ~}{ }^{2 \#}$, Jihwan Lee ${ }^{1}$, Hanjin $\mathrm{Oh}^{1}$, Jiseon An ${ }^{1}$, Gokmi Kim, \\ Sungdae Lee ${ }^{4}$, Suhyup Lee ${ }^{5}$, Hyeun Bum Kim ${ }^{6 *}$ and Jinho Cho ${ }^{1 *}$ \\ ${ }^{1}$ Department of Animal Science, Chungbuk National University, Cheongju 28644, Korea \\ ${ }^{2}$ Department of Animal Science and Biotechnology, Chungnam National University, Daejeon 34134, Korea \\ ${ }^{3}$ Yonam College, Cheonan 31005, Korea \\ ${ }^{4}$ National Institute of Animal Science, Wanju 55365, Korea \\ ${ }^{5}$ Department of Swine Science, Korea National College of Agriculture and Fisheries, Jeonju 54874, Korea \\ ${ }^{6}$ Department of Animal Resource and Science, Dankook University, Cheonan 31116, Korea
}

\begin{abstract}
The effects of arginine (Arg) and methionine (Met) supplementation on nutrient use in pigs were determined under hot season conditions. A total of five experimental diets including basal diet (CON) were supplemented with two types of amino acids (Arg and Met) and two different amounts of amino acids $(0.2 \%$ and $0.4 \%)$. Under hot season condition, pigs fed with additional Arg were significantly higher in average daily gain (ADG) than the CON group and the ADG increased linearly $(p<0.05)$ with increasing Arg supplementation. But there was no significant difference with Met supplementation $(p>0.05)$. The apparent ileal digestibility (AID) of amino acids had no significant difference among treatments $(p>0.05)$, while d-reactive oxygen metabolites ( $d-R O M s$ ) concentration in treatments with Arg supplementation, were significantly higher $(p<0.05)$ than other treatments. In conclusion, exposure of pigs to heat stress does not affect the AID of amino acid, whereas pig fed with additional Arg improved ADG and feed efficiency under heat stress condition.
\end{abstract}

Keywords: Apparent ileal digestibility, Arginine, Heat stress, Methionine, Weaning pig

\section{INTRODUCTION}

Heat stress (HS) causes a decrease in the growth of pigs causing in major losses to the pork production. Especially, pigs are affected by HS in tropical or subtropical regions with hot seasons. Pigs suffering from HS show decreased feed intake [1], increased body temperature [2], reduced growth and increased veterinary costs [3]. Also, the temperature inside piggery is changed by the external temperature. Under HS, pigs increase their peripheral blood circulation to advance body thermolysis. The peripheral blood vessels are dilated with occurred vasoconstriction to the entire splanchnic blood vessels [4]. HS is seriously affecting the small intestine that is major tissues [5] to upregulate heat shock proteins during heat stress [6] and reduce oxygen and nutrient supply to gastrointestinal tract tissue [7] which may cause serious damage to the intestinal epithelia. Decreased intestinal villi height is generally observed in HS 
Hanjin Oh

https://orcid.org/0000-0002-3396-483X Jiseon An

https://orcid.org/0000-0002-9205-8095

Gokmi Kim

https://orcid.org/0000-0003-1053-4535

Sungdae Lee

https://orcid.org/0000-0002-9167-4099

Suhyup Lee

https://orcid.org/0000-0001-8996-3740

Hyeun Bum Kim

https://orcid.org/0000-0003-1366-6090

Jinho Cho

https://orcid.org/0000-0001-7151-0778

\section{Competing interests}

The authors declare that they have no conflict of interest.

Funding sources

This work was financially supported by the Research Year of Chungbuk National University in 2020.

Acknowledgements

Not applicable.

Availability of data and material Upon reasonable request, the datasets of this study can be available from the corresponding author.

Authors' contributions

Conceptualization: Yun W.

Data curation: Lee J, Oh H, Lee SD.

Formal analysis: An J, Kim G.

Methodology: Kim HB, Cho J.

Software: Lee J, Lee SH

Validation: Song M.

Investigation: Yun W.

Writing - original draft: Yun W, Cho J.

Writing - review \& editing: Kim HB, Cho J.

Ethics approval and consent to participate The protocol for the two experiments was approved by the Institutional Animal Care and Use Committee of Chungbuk National University, Cheongju, Korea. pigs [8] with cellular proliferation and membrane function changes [9]. In addition, dramatic decrease was observed in the genes coding the synthesis of amino acid transporters in the small intestine of HS pigs [10]. HS transmutes organism physiology, metabolism, homeostasis and increases the intestinal temperature [11]. Reduced proliferation of intestinal cells [9] and increased creation of reactive oxygen species (ROS) [12] are also caused by HS. Some amino acids such as arginine (Arg) and methionine (Met) seem to contribute to restoring intestinal epithelia [13] as well as destroy ROS [14]. Thus, we investigated the effect of Arg and Met supplementation on nutrient use in growing pigs in high ambient temperature.

\section{MATERIALS AND METHODS}

The protocol for the two experiments was approved by the Institutional Animal Care and Use Committee of Chungbuk National University, Cheongju, Korea.

\section{Experiment design and housing}

In this experiment, a total of 10 crossbred (Duroc $\times$ Landrace $\times$ Yorkshire) barrows were assigned to five treatments over five periods in a $5 \times 5$ Latin square design with two replicates per period. The pigs (average of initial body weight was $16.2 \pm 1.2 \mathrm{~kg}$ ) with T-type cannulas transplanted at approximately $15 \mathrm{~cm}$ before the distal ileum were individually confined to metabolic cages $(0.8 \mathrm{~m} \times$ $0.5 \mathrm{~m} \times 0.5 \mathrm{~m})$ in an environment-controlled room. The experiment was carried out in summer climate (August) in South Korea and the average relative humidity was $85.4 \%$. Surgery and recovery were conducted according to Sauer et al. [15]. The temperature and relative humidity were based on experimental piggeries in the summer seasons in Korea (Fig. 1).

\section{Diets and feeding}

Table 1 represents the nutrient contents and the feed formulation used in this experiment. During the five weeks of the experiment, pigs were assigned to one of five dietary treatments, representing supplementation with two types of amino acids (Arg and Met) and two different amounts of amino acids $(0.2 \%$ and $0.4 \%)$. The daily feed ration was regulated to 2.7 times the maintenance

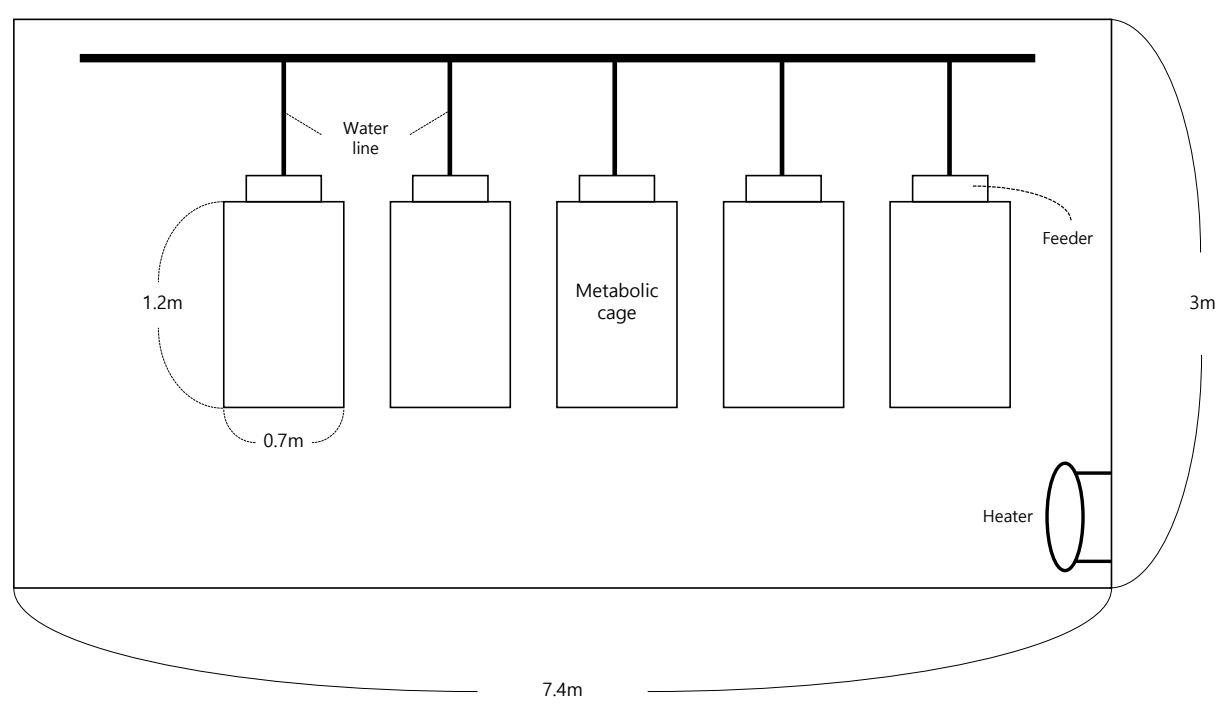

Fig. 1. Schematic drawing of experimental room. 
Table 1. Formula and chemical composition of the basal diets (as-fed basis)

\begin{tabular}{|c|c|c|c|c|c|}
\hline \multirow{2}{*}{ Ingredients (\%) } & \multirow{2}{*}{ CON } & \multicolumn{2}{|c|}{ Arginine } & \multicolumn{2}{|c|}{ Methionine } \\
\hline & & 0.2 & 0.4 & 0.2 & 0.4 \\
\hline Corn & 58.16 & 58.16 & 58.16 & 58.16 & 58.16 \\
\hline Soybean meal & 27.42 & 27.22 & 27.02 & 27.22 & 27.02 \\
\hline Wheat & 3.00 & 3.00 & 3.00 & 3.00 & 3.00 \\
\hline Canola meal & 2.00 & 2.00 & 2.00 & 2.00 & 2.00 \\
\hline Canola oil & 3.29 & 3.29 & 3.29 & 3.29 & 3.29 \\
\hline Wheat bran & 3.00 & 3.00 & 3.00 & 3.00 & 3.00 \\
\hline Limestone & 0.63 & 0.63 & 0.63 & 0.63 & 0.63 \\
\hline Dicalcium phosphate & 1.57 & 1.57 & 1.57 & 1.57 & 1.57 \\
\hline Lysine & 0.24 & 0.24 & 0.24 & 0.24 & 0.24 \\
\hline Arginine & - & 0.20 & 0.40 & - & - \\
\hline Methionine & 0.08 & 0.08 & 0.08 & 0.28 & 0.48 \\
\hline Threonine & 0.03 & 0.03 & 0.03 & 0.03 & 0.03 \\
\hline Choline (Cl) & 0.03 & 0.03 & 0.03 & 0.03 & 0.03 \\
\hline Mineral premix ${ }^{11}$ & 0.10 & 0.10 & 0.10 & 0.10 & 0.10 \\
\hline Vitamin premix ${ }^{2)}$ & 0.20 & 0.20 & 0.20 & 0.20 & 0.20 \\
\hline Salt & 0.25 & 0.25 & 0.25 & 0.25 & 0.25 \\
\hline Total & 100 & 100 & 100 & 100 & 100 \\
\hline \multicolumn{6}{|l|}{ Calculated value } \\
\hline Metabolizable energy (cal/g) & 3,381 & 3,374 & 3,368 & 3,374 & 3,368 \\
\hline Crude protein & 19.80 & 19.90 & 20.01 & 19.90 & 20.01 \\
\hline Arginine & 1.12 & 1.32 & 1.52 & 1.12 & 1.12 \\
\hline Methionine & 0.40 & 0.40 & 0.40 & 0.60 & 0.80 \\
\hline \multicolumn{6}{|l|}{ Analyzed value } \\
\hline \multicolumn{6}{|l|}{ Indispensable amino acid } \\
\hline Arginine & 1.10 & 1.31 & 1.53 & 1.10 & 1.10 \\
\hline Histidine & 0.59 & 0.59 & 0.59 & 0.59 & 0.59 \\
\hline Isoleucine & 0.76 & 0.76 & 0.76 & 0.76 & 0.76 \\
\hline Leucine & 1.83 & 1.83 & 1.83 & 1.83 & 1.83 \\
\hline Lysine & 1.18 & 1.18 & 1.18 & 1.18 & 1.18 \\
\hline Phenylalanine & 0.48 & 0.48 & 0.48 & 0.70 & 0.89 \\
\hline Threonine & 1.06 & 1.06 & 1.06 & 1.06 & 1.06 \\
\hline Methionine & 0.74 & 0.74 & 0.74 & 0.74 & 0.74 \\
\hline Tryptophan & 1.09 & 1.09 & 1.09 & 1.09 & 1.09 \\
\hline \multicolumn{6}{|l|}{ Dispensable amino acid } \\
\hline Alanine & 1.08 & 1.08 & 1.08 & 1.08 & 1.08 \\
\hline Aspartic acid & 1.24 & 1.24 & 1.24 & 1.24 & 1.24 \\
\hline Cysteine & 0.37 & 0.37 & 0.37 & 0.37 & 0.37 \\
\hline Glutamic acid & 3.70 & 3.70 & 3.70 & 3.70 & 3.70 \\
\hline Glycine & 0.83 & 0.83 & 0.83 & 0.83 & 0.83 \\
\hline Proline & 1.27 & 1.27 & 1.27 & 1.27 & 1.27 \\
\hline Serine & 0.78 & 0.78 & 0.78 & 0.78 & 0.78 \\
\hline Tyrosine & 0.65 & 0.65 & 0.65 & 0.65 & 0.65 \\
\hline
\end{tabular}

${ }^{1)}$ Provided per $\mathrm{kg}$ of complete diet: vitamin A, 12,000 IU; vitamin $\mathrm{D}_{3}, 2,500 \mathrm{IU}$; vitamin $\mathrm{E}, 30 \mathrm{IU}$; vitamin $\mathrm{K}_{3}, 3$ mg; D-pantothenic acid, $15 \mathrm{mg}$; nicotinic acid, $40 \mathrm{mg}$; choline, $400 \mathrm{mg}$; and vitamin $\mathrm{B}_{12}, 12 \mu \mathrm{g}$.

${ }^{2)}$ Provided per kg of complete diet: $\mathrm{Fe}$ (as $\mathrm{FeSO}_{4} \cdot 7 \mathrm{H}_{2} \mathrm{O}$ ), $90 \mathrm{mg}$; Cu (as $\mathrm{CuSO}_{4} \cdot 5 \mathrm{H}_{2} \mathrm{O}$ ), $8.5 \mathrm{mg} ; \mathrm{Zn}\left(\right.$ as $\mathrm{ZnSO}{ }_{4}$ ), $100 \mathrm{mg} ; \mathrm{Mn}$ $\left(\mathrm{MnO}_{2}\right), 50 \mathrm{mg}$; I (as KI), $0.35 \mathrm{mg}$; $\mathrm{Se}\left(\right.$ as $\left.\mathrm{Na}_{2} \mathrm{SeO}_{3} \cdot 5 \mathrm{H}_{2} \mathrm{O}\right), 0.30 \mathrm{mg}$. 
requirement for digestible energy $\left(2.7 \times 110 \mathrm{kcal}\right.$ of $\left.\mathrm{DE} / \mathrm{kg} \mathrm{BW} \mathrm{BW}^{0.75} ;[16]\right)$. The daily feed ration was divided their allowance in half and fed at 08:00 and 20:00 hours. The diets were blended with water in a 1:1 ratio $(\mathrm{Wt} / \mathrm{Wt})$ before feeding and pigs had free approach to water during the experiment.

\section{Sampling and analysis}

The pigs were weighed at the start of each period and the amount of feed consumed during each period was recorded. Each experiment period is 7 days and it consists of a 4 days adaptation and a 3 days sampling for collecting feces and urine. The ileal digesta was continuously collected from all pigs for 12 hours starting at 08:00 hours. Plastic bags were equipped to the T-cannula until filled with ileal digesta but no longer than 15 minutes. Ileal digesta was collected for each pig and frozen at $-20^{\circ} \mathrm{C}$ immediately after sampling. Before analyses, the digesta samples were thawed, homogenized, subsampled and freeze-dried. Diets and ileal digesta were analyzed for dry matter (AOAC method 930.15) and crude protein (AOAC method 990.03). The gross energy of diets and ileal digesta were analyzed using an oxygen bomb calorimeter (Parr Instruments, Moline, IL, USA). The urinary nitrogen was analyzed (AOAC method 990.03).

\section{Statistical analysis}

The data for effects of Arg and Met supplementation on growth performance, nutrient digestibility and plasma profile were subjected to an analysis of variance using PROC GLM of SAS (Statistical Analysis System 9.1, SAS Institute, Cary, NC, USA). Duncan's multiple range test was used to compare differences among the treatment groups including the control group. Significant difference among feeding treatments was shown as $p<0.05$, while no significant differences were shown as $p>0.05$. Polynomial orthogonal contrasts were performed to compare differences in type (Arg vs. Met) and level (0.2 vs. 0.4).

\section{RESULTS}

Fig. 2 represents the mean values of variations in temperature, at intervals of 3 hours during the experimental period $(35 \mathrm{~d})$. At 18:00 hours to a maximum of $35.6^{\circ} \mathrm{C}$ and the lowest temperature was $26.1^{\circ} \mathrm{C}$ at 03:00 hours. Growth performance data are summarized in Table 2. Pigs fed with

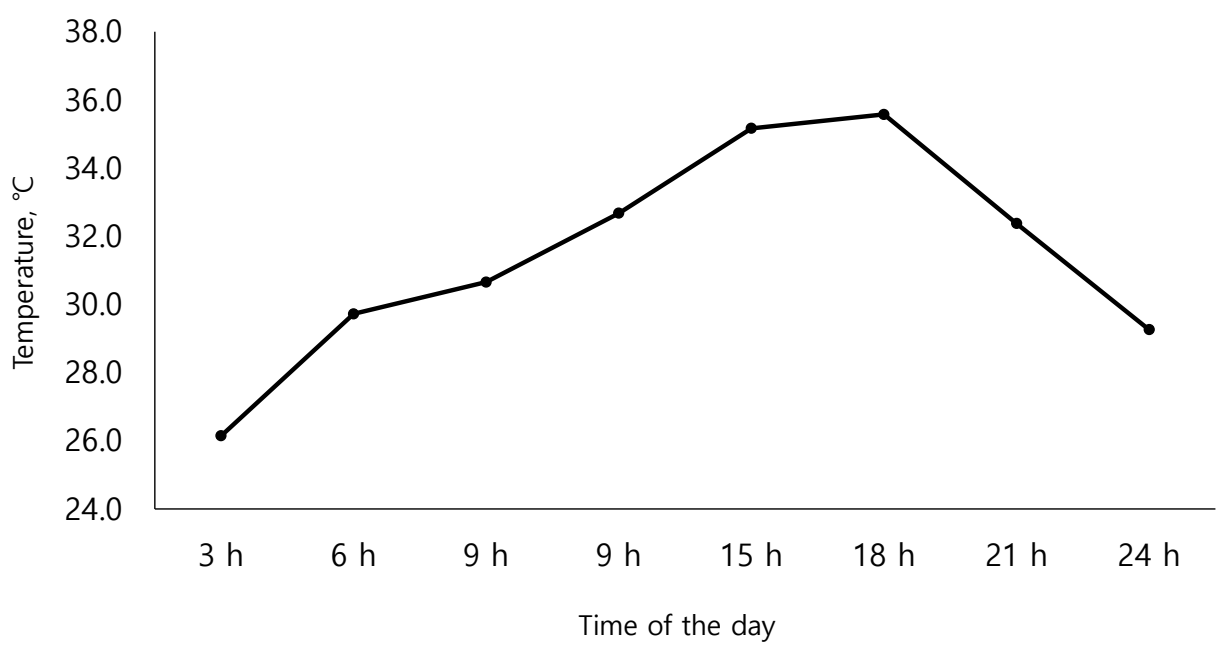

Fig. 2. Average daily temperature change in the experimental room during 35 days. 
additional Arg were significantly higher in average daily gain (ADG) than the CON group $(p<$ $0.05)$, and ADG increased linearly with increasing Arg supplementation $(p<0.05)$. But there was no significant difference with Met supplementation $(p>0.05)$. Average daily feed intake (ADFI) has no significant difference according to additional supplementation with Arg and Met $(p>0.05)$. Feed efficiency increased linearly, with increasing $(p<0.05)$ amounts of additional Arg and Met. Table 3 presents the effects of Arg and Met supplementation level on the apparent total tract digestibility under the HS condition. The apparent total tract digestibility (ATTD) of dry matter $(\mathrm{DM})$ and crude protein $(\mathrm{CP})$ were not significantly different among treatments $(p>0.05)$. Table 4 presents the effects of Arg and Met supplementation on plasma profile in weaning pigs under HS condition. Protein, blood urea nitrogen (BUN) and cortisol concentration in plasma, did not significantly differ $(p>0.05)$, while $\mathrm{d}-\mathrm{ROM}$ s concentration in treatments with Arg supplementation were significantly higher $(p<0.05)$ than other treatments. Table 5 presents the effects of arginine and methionine supplementation on apparent ileal digestibility (AID) of amino acids in weaning pigs under high ambient temperature. The AID of amino acid had no significant differences among treatments $(p>0.05)$.

\section{DISCUSSION}

The experimental environment was based on the temperature rising due to the summer climate and the temperature of the experimental piggery recorded the highest temperature at 18 hours. Pigs fed

Table 2. Effects of arginine and methionine supplementation on growth performance in weaning pigs under high ambient temperature

\begin{tabular}{|c|c|c|c|c|c|c|c|c|c|}
\hline \multirow{2}{*}{ Items } & \multirow{2}{*}{ CON } & \multicolumn{2}{|c|}{ Arginine (Arg) } & \multicolumn{2}{|c|}{ Methionine (Met) } & \multirow{2}{*}{ SE } & \multirow{2}{*}{$p$-value } & \multicolumn{2}{|c|}{$p$-value of contrast } \\
\hline & & 0.2 & 0.4 & 0.2 & 0.4 & & & Arg vs. Met & 0.2 vs. 0.4 \\
\hline ADG (g) & $222^{a}$ & $235^{\mathrm{bL}}$ & $247^{\mathrm{bL}}$ & $220^{a}$ & $225^{a}$ & 4 & 0.031 & 0.016 & 0.030 \\
\hline$G: F$ & $0.42^{\mathrm{a}}$ & $0.44^{\mathrm{abl}}$ & $0.46^{\mathrm{bL}}$ & $0.42^{\mathrm{aL}}$ & $0.45^{\mathrm{abl}}$ & 0.01 & 0.014 & 0.120 & 0.205 \\
\hline
\end{tabular}

${ }^{a, b}$ Means in the same row with different superscripts differ $(p<0.05)$.

${ }^{L} p$-value of Linear coefficients $(p<0.05)$.

$\mathrm{SE}$, standard error; ADG, average daily gain; ADFI, average daily feed intake, G:F, gain to feed ratio (feed efficiency).

Table 3. Effects of arginine and methionine supplementation on apparent total tract digestibility in weaning pigs under high ambient temperature

\begin{tabular}{|c|c|c|c|c|c|c|c|c|c|}
\hline \multirow{2}{*}{ Items (\%) } & \multirow{2}{*}{ CON } & \multicolumn{2}{|c|}{ Arginine (Arg) } & \multicolumn{2}{|c|}{ Methionine (Met) } & \multirow{2}{*}{ SE } & \multirow{2}{*}{$p$-value } & \multicolumn{2}{|c|}{$p$-value of contrast } \\
\hline & & 0.2 & 0.4 & 0.2 & 0.4 & & & Arg vs. Met & 0.2 vs. 0.4 \\
\hline Dry matter & 82.1 & 82.1 & 82.7 & 82.5 & 83.6 & 0.9 & 0.772 & 0.704 & 0.306 \\
\hline Crude protein & 77.5 & 79.4 & 79.2 & 79.2 & 79.6 & 2.7 & 0.205 & 0.815 & 0.775 \\
\hline
\end{tabular}

$\mathrm{SE}$, standard error.

Table 4. Effects of arginine and methionine supplementation on plasma profile in weaning pigs under heat stress condition

\begin{tabular}{|c|c|c|c|c|c|c|c|c|c|}
\hline \multirow{2}{*}{ Items } & \multirow{2}{*}{ CON } & \multicolumn{2}{|c|}{ Arginine (Arg) } & \multicolumn{2}{|c|}{ Methionine (Met) } & \multirow{2}{*}{ SE } & \multirow{2}{*}{$p$-value } & \multicolumn{2}{|c|}{$p$-value of contrast } \\
\hline & & 0.2 & 0.4 & 0.2 & 0.4 & & & Arg vs. Met & 0.2 vs. 0.4 \\
\hline Protein $(\mathrm{g} / \mathrm{dL})$ & 5.16 & 5.22 & 5.31 & 5.14 & 5.20 & 0.11 & 0.555 & 0.212 & 0.218 \\
\hline BUN (mg/dL) & 3.84 & 3.71 & 3.77 & 3.97 & 3.99 & 0.23 & 0.600 & 0.180 & 0.704 \\
\hline $\mathrm{d}-\mathrm{ROMs}\left(\mathrm{mg} / \mathrm{dL}\left[\mathrm{H}_{2} \mathrm{O}_{2}\right]\right)$ & $60.7^{\mathrm{a}}$ & $48.1^{\mathrm{b}}$ & $47.3^{\mathrm{b}}$ & $58.7^{\mathrm{b}}$ & $57.6^{\mathrm{b}}$ & 2.08 & 0.001 & 0.001 & 0.613 \\
\hline Cortisol ( $\mu \mathrm{g} / \mathrm{dL})$ & 1.29 & 1.24 & 1.21 & 1.27 & 1.25 & 0.10 & 0.630 & 0.588 & 0.497 \\
\hline
\end{tabular}

${ }^{a, b}$ Means in the same row with different superscripts differ $(p<0.05)$.

$\mathrm{SE}$, standard error; BUN, blood urea nitrogen; ROMs, reactive oxygen metabolites. 
Table 5. Effects of arginine and methionine supplementation on apparent ileal digestibility of amino acids in weaning pigs under heat stress condition

\begin{tabular}{|c|c|c|c|c|c|c|c|c|c|}
\hline \multirow{2}{*}{ Items (\%) } & \multirow{2}{*}{ CON } & \multicolumn{2}{|c|}{ Arginine (Arg) } & \multicolumn{2}{|c|}{ Methionine (Met) } & \multirow{2}{*}{ SE } & \multirow{2}{*}{$p$-value } & \multicolumn{2}{|c|}{$p$-value of contrast } \\
\hline & & 0.2 & 0.4 & 0.2 & 0.4 & & & Arg vs. Met & 0.2 vs. 0.4 \\
\hline \multicolumn{10}{|c|}{ Indispensable amino acid } \\
\hline Arginine & 86.8 & 86.2 & 86.4 & 86.3 & 86.2 & 1.2 & 0.713 & 0.816 & 0.748 \\
\hline Histidine & 81.9 & 81.9 & 81.3 & 81.7 & 81.4 & 1.5 & 0.612 & 0.554 & 0.486 \\
\hline Isoleucine & 77.3 & 77.8 & 77.7 & 77.8 & 77.5 & 1.4 & 0.804 & 0.879 & 0.810 \\
\hline Leucine & 81.7 & 81.4 & 81.6 & 81.4 & 81.5 & 1.8 & 0.696 & 0.801 & 0.733 \\
\hline Lysine & 80.9 & 80.0 & 80.4 & 80.6 & 80.3 & 1.9 & 0.787 & 0.317 & 0.249 \\
\hline Phenylalanine & 80.3 & 80.3 & 80.4 & 80.3 & 80.3 & 0.9 & 0.682 & 0.863 & 0.795 \\
\hline Threonine & 69.8 & 70.1 & 70.3 & 70.7 & 70.4 & 1.1 & 0.480 & 0.308 & 0.608 \\
\hline Methionine & 83.9 & 82.6 & 83.8 & 81.9 & 82.3 & 1.2 & 0.024 & 0.039 & 0.592 \\
\hline Tryptophan & 80.4 & 80.3 & 80.1 & 82.1 & 81.7 & 2.0 & 0.771 & 0.793 & 0.725 \\
\hline Valine & 74.4 & 75.0 & 75.3 & 74.9 & 75.1 & 2.1 & 0.088 & 0.382 & 0.132 \\
\hline \multicolumn{10}{|c|}{ Dispensable amino acid } \\
\hline Alanine & 73.5 & 73.1 & 73.4 & 72.9 & 71.5 & 1.4 & 0.341 & 0.340 & 0.366 \\
\hline Aspartic acid & 68.7 & 66.8 & 67.2 & 68.4 & 67.5 & 2.1 & 0.603 & 0.274 & 0.348 \\
\hline Cysteine & 69.6 & 71.2 & 70.4 & 71.1 & 69.6 & 1.5 & 0.305 & 0.248 & 0.194 \\
\hline Glutamic acid & 81.5 & 82.0 & 81.7 & 80.9 & 81.8 & 2.4 & 0.891 & 0.880 & 0.731 \\
\hline Glycine & 62.1 & 63.1 & 62.4 & 62.3 & 62.8 & 1.7 & 0.172 & 0.244 & 0.185 \\
\hline Proline & 68.6 & 67.7 & 68 & 68.8 & 67.9 & 2.0 & 0.573 & 0.765 & 0.780 \\
\hline Serine & 70.7 & 71.2 & 70.8 & 70.1 & 71.6 & 1.9 & 0.762 & 0.309 & 0.518 \\
\hline Tyrosine & 75.6 & 76.5 & 76.9 & 75.2 & 75.2 & 1.5 & 0.851 & 0.297 & 0.648 \\
\hline
\end{tabular}

SE, standard error.

with additional Arg were significantly higher in $\mathrm{ADG}$ than the $\mathrm{CON}$ group. Also, $\mathrm{ADG}$ and feed efficiency increased linearly with increasing Arg supplementation. The HS reduced an animal's intestinal efficiency for nutrient absorption as proved by decreased height of intestinal villi in pigs [17] and decreased feed intake [1]. These results cause degradation of nutrient use because of the high ambient temperature. When pigs are under HS condition, blood is moved to the peripheral tissue to increase thermo diffusional in the body [4]. Accordingly, HS may cause hypoxia, hyperthermia and inflammation in gastrointestinal tract [18], all of which can trigger oxidative stress. Although depends on the intensity and the duration of HS, it has been reported that markers of intestinal oxidative stress increase in the intestine of HS pigs [2]. The Arg is a nutritionally important amino acid and has various physiological functions in the animal body [19]. One of these functions is to reduce superoxide release and increase antioxidant ability [20]. The Arg produces proline, polyamines, nitric oxide and glutamine during metabolic process [21]. For example, these metabolites can alleviate the oxidative stress damage [22], enhance the immune function [23] and regulate protein synthesis [24]. The ROS is sustainedly produced as a byproduct of cell respiration in the mitochondria [25]. The HS causes overproduction of ROS, which increases oxidative damage to muscle cells [26]. Also, Liu et al. [27] reported significant mitochondrial damage in the jejunal epithelium of heat-stressed pigs. The Arg seems to facilitate restoration of intestinal epithelia [13] and destroy ROS [14]. Additionally, Arg is a synthetic precursor of nitric oxide [13], a potent vasodilator that increases blood flow for body heat dissipation [28]. Large amounts of Arg are used for production of creatine whose anti-oxidative function [14] may facilitate in ameliorating the impact of HS-related overproduction of mitochondrial ROS [12]. At thermoneutral temperature, Arg content in 
the feed of pigs will be sufficient. Because Arg is synthesized in several organs, especially in kidneys using citrulline as a precursor [13]. Conversely, under high ambient temperature, requirement of Arg may increase to remove ROS caused by HS. Hence, additional supplementation of Arg is used to cope with HS that affects reduction of damage caused by ROS. In conclusion, exposure of pigs to HS does not affect AID of amino acid. However, results of ADG and feed efficiency in treatments fed with additional Arg were greater than other treatments. Thus, pigs fed with supplementation of Arg may facilitate reduction of negative effects such as increasing oxidative stress according to HS.

\section{REFERENCES}

1. Le Bellego L, Van Milgen J, Noblet J. Effect of high temperature and low-protein diets on the performance of growing-finishing pigs. J Anim Sci. 2002;80:691-701.

2. Pearce SC, Mani V, Weber TE, Rhoads RP, Patience JF, Baumgard LH, et al. Heat stress and reduced plane of nutrition decreases intestinal integrity and function in pigs. J Anim Sci. 2013;91:5183-93.

3. Renaudeau D, Gourdine JL, St-Pierre NR. A meta-analysis of the effects of high ambient temperature on growth performance of growing-finishing pigs. J Anim Sci. 2011;89:2220-30.

4. Collin A, Lebreton F, Fillaut M, Vincent A, Thomas F, Herpin P. Effects of exposure to high temperature and feeding level on regional blood flow and oxidative capacity of tissues in piglets. Exp Physiol. 2001;86:83-91.

5. Kregel KC. Heat shock proteins: modifying factors in physiological stress responses and acquired thermotolerance.J Appl Physiol. 2002;92:2177-86.

6. Flanagan SW, Ryan AJ, Gisolfi CV, Moseley PL. Tissue-specific HSP70 response in animals undergoing heat stress. Am J Physiol. 1995;268:R28-32.

7. Hinnebusch BF, Ma Q, Henderson JW, Siddique A, Archer SY, Hodin RA. Enterocyte response to ischemia is dependent on differentiation state.J Gastrointest Surg. 2002;6:403-9.

8. Pearce SC, Mani V, Boddicker RL, Johnson JS, Weber TE, Ross JW, et al. Heat stress reduces intestinal barrier integrity and favors intestinal glucose transport in growing pigs. PLOS ONE. 2013;8:e70215.

9. Sonna LA, Fujita J, Gaffin SL, Lilly CM. Effects of heat and cold stress on mammalian gene expression.J Appl Physiol. 2002;92:1725-42.

10. Morales A, Grageola F, García H, Arce N, Araiza B, Yáñez J, et al. Performance, serum amino acid concentrations and expression of selected genes in pair-fed growing pigs exposed to high ambient temperatures. J Anim Physiol Anim Nutr. 2014;98:928-35.

11. Morales A, Buenabad L, Castillo G, Arce N, Araiza BA, Htoo JK, et al. Low protein-amino acid supplemented diets for growing pigs: effect on expression of amino acid transporters, serum concentration, performance and carcass composition.J Anim Sci. 2015;93:2154-64.

12. Kikusato M, Toyomizu M. Crucial role of membrane potential in heat stress-induced overproduction of reactive oxygen species in avian skeletal muscle mitochondria. PLOS ONE. 2013;8:e64412.

13. Wu G, Bazer FW, Davis TA, Kim SW, Li P, Rhoads JM, et al. Arginine metabolism and nutrition in growth, health and disease. Amino Acids. 2009;37:153-68.

14. Lawler JM, Barnes WS, Wu G, Song W, Demaree S. Direct antioxidant properties of creatine. Biochem Biophys Res Commun. 2002;290:47-52.

15. Sauer WC, Jørgensen H, Berzins R. A modified nylon bag technique for determining apparent digestibilities of protein in feedstuffs for pigs. Can J Anim Sci. 1983;63:233-7.

16. NRC [National Research Council]. Nutrient requirements for swine. 10th ed. Washington, 
DC: National Academic Press; 1998.

17. Pearce SC, Sanz-Fernandez MV, Hollis JH, Baumgard LH, Gabler NK. Short-term exposure to heat stress attenuates appetite and intestinal integrity in growing pigs. J Anim Sci. 2014;92:5444-54.

18 Zuhl M, Schneider S, Lanphere K, Conn C, Dokladny K, Moseley P. Exercise regulation of intestinal tight junction proteins. Br J Sports Med. 2014;48:980-6.

19. Wu G, Bazer FW, Davis TA, Jaeger LA, Johnson GA, Kim SW, et al. Important roles for the arginine family of amino acids in swine nutrition and production. Livest Sci. 2007;112:8-22.

20. Petrović V, Buzadžić B, Korać A, Vasilijević A, Janković A, Mićunović K, et al. Antioxidative defence alterations in skeletal muscle during prolonged acclimation to cold: role of $\mathrm{L}$-arginine/ NO-producing pathway.J Exp Biol. 2008;211:114-20.

21. Liao XH, Majithia A, Huang X, Kimmel AR. Growth control via TOR kinase signaling, an intracellular sensor of amino acids and energy availability, with crosstalk potential to proline metabolism. Amino Acids. 2008;35:761-70.

22. Hamasu K, Haraguchi T, Kabuki Y, Adachi N, Tomonaga S, Sato H, et al. L-proline is a sedative regulator of acute stress in the brain of neonatal chicks. Amino Acids. 2009;37:377-82.

23. Tan B, Li XG, Kong X, Huang R, Ruan Z, Yao K, et al. Dietary L-arginine supplementation enhances the immune status in early-weaned piglets. Amino acids. 2009;37:323-31.

24. Yao K, Yin YL, Chu W, Liu Z, Deng D, Li T, et al. Dietary arginine supplementation increases mTOR signaling activity in skeletal muscle of neonatal pigs. J Nutr. 2008;138:867-72.

25. Slimen IB, Najar T, Ghram A, Dabbebi H, Mrad MB, Abdrabbah M. Reactive oxygen species, heat stress and oxidative-induced mitochondrial damage. a review. Int J Hyperther. 2014;30:513-23.

26. Kikusato M, Yoshida H, Furukawa K, Toyomizu M. Effect of heat stress-induced production of mitochondrial reactive oxygen species on NADPH oxidase and heme oxygenase- 1 mRNA levels in avian muscle cells. J Therm Biol. 2015;52:8-13.

27. Liu F, Yin J, Du M, Yan P, Xu J, Zhu X, et al. Heat-stress-induced damage to porcine small intestinal epithelium associated with downregulation of epithelial growth factor signaling. J Anim Sci. 2009;87:1941-9.

28. Ogoh S, Sato K, Okazaki K, Miyamoto T, Hirasawa A, Morimoto K, et al. Blood flow distribution during heat stress: cerebral and systemic blood flow. J Cereb Blood Flow Metab. 2013;33:1915-20. 